DOI: $10.17234 / S R A Z .65 .34$

UDK: 811.135.1'27

UDK: 811.135.1'28

Original scientific paper

Primit la 26 aprilie 2020

Acceptat pentru publicare la 25 noiembrie 2020

\title{
Atitudine descriptivă și comentariu metalingvistic în ALRR - Transilvania
}

\author{
Rozalia Colciar \\ Institutul de Lingvistică și Istorie Literară "Sextil Pușcariu" al Academiei Române, \\ Cluj-Napoca, România \\ rozaliac@yahoo.com
}

Lucrarea noastră urmărește, pe baza unui material excerptat din ALRR - Transilvania, modul de exprimare a atitudinii/reacției subiectului vorbitor față de fenomenele lingvistice, de la simpla percepție a propriului idiom, la percepția diferențelor lingvistice dintre două idiomuri învecinate.

Această atitudine se exprimă prin intermediul comentariului metalingvistic: desprinderea elementelor lingvistice din contextul de comunicare și aprecierea lor printr-un metalimbaj adecvat. ALRR- Transilvania înregistrează comentarii: 1. provocate, solicitate și dirijate de către anchetator (aprecieri generale și exemple concrete privind deosebirile dintre graiul din localitatea anchetată și localităţile vecine); 2. spontane (accidentale, generate de dorința de exprimare proprie a subiectului, indicații cu rol de "glosare" a termenului solicitat). Ele vizează în special fapte de natură fonetică și lexicală.

Comentariile metalingvistice exprimă atât capacitatea de reflectare de către subiectul vorbitor a faptelor lingvistice aparținând idiolectului propriu, cât și capacitatea de descriere și explicitare a acestora, ca formă de manifestare a conștiinței lingvistice. Fenomenul dialectal trebuie deci abordat și prin prisma dimensiunii lui interacționale și sociale.

Cuvinte-cheie: ALRR-Transilvania, atitudine descriptivă, comentariu metalingvistic, comentarii provocate, comentarii spontane.

1. Cercetarea dialectală și-a extins obiectul odată cu dezvoltarea studiilor de socio- și pragmalingvistică, studii care au pus în evidență problema reacției subiectului vorbitor față de fenomenele lingvistice. În cursul anchetei dialectale, reacțiile informatorilor sunt însoțite adesea de comentarii referitoare la răspunsurile date, răspunsuri consemnate în atlasele lingvistice și în culegerile de texte dialectale. Aceste comentarii metalingvistice presupun desprinderea elementelor lingvistice din contextul de comunicare și aprecierea lor printr-un metalimbaj adecvat.

Dialectologia și geografia lingvistică românească au cunoscut, de-a lungul anilor, o serie de contribuții care au avut ca temă reacția implicită (neformulată) sau explicită (formulată în comentarii metalingvistice) a subiectului vorbitor față de fenomenele lingvistice (Cazacu 1957, Sala 1957, Teaha 1970, Faiciuc 1985, Vulpe 
2004, Colciar 2019). În funcție de planul și de modul în care se manifestă, aceste reacții ale subiectului vorbitor pot fi clasificate, după Hoenigswald (1966), în: a) reacții secundare, care se referă la atitudini neexprimate, manifestate prin modul în care subiectul selectează faptele de limbă; b) reacții terțiare, referitoare la comentariile explicite și la opiniile asupra limbajului, exprimate de nonlingvist (Vulpe 2004: 419). Acestea din urmă vizează două categorii de comentarii: 1. provocate și 2 . spontane.

2. Lucrarea de față urmărește modul de exprimare a reacției/atitudinii subiectului vorbitor față de fenomenele lingvistice pe baza unor date extrase din ALRR - Transilvania, de la simpla percepție a propriului idiom, la percepția diferențelor lingvistice dintre două idiomuri învecinate. Această atitudine descriptivă referitoare la diferențele diatopice și diastratice se manifestă prin intermediul comentariilor metalingvistice înregistrate în timpul anchetelor pe teren ale căror rezultate s-au concretizat, până acum, în patru volume publicate între anii 1992 - 2006.

2.1. Ancheta dialectală reprezintă o „formă de comunicare” (Dumistrăcel et alii 1997: 32) ce reflectă competența expresivă a subiectului, capacitatea acestuia de a structura „«discursuri» în conformitate cu circumstanțele" (Coșeriu 1994: 136). Desfășurată după o „,convenție”, ea are la bază dimensiunea autoreferențială a limbajului; actul fundamental de limbaj prin care se realizează, la nivel discursiv, este solicitarea, interogația fiind un caz particular de solicitare (Manu Magda 2003: 45), un act verbal inițiator de conversație.

În acest context, comentariile provocate sunt solicitate și dirijate de anchetator prin întrebări programate în chestionarul după care se desfășoară ancheta lingvistică. În anchetele pentru ALRR - Transilvania, ca de altfel și pentru anchetele celelorlalte atlase regionale desfășurate după Chestionarul NALR, comentariile provocate au fost obținute ca răspunsuri la chestiunea 20, programată în partea introductivă: „Care dintre localitățile învecinate se deosebește din punctul de vedere al graiului de graiul din localitatea anchetată?". ${ }^{1}$ Răspunsurile, generoase în sugestii de interpretare, compensează lipsa unui număr mai mare de întrebări menite a surprinde mai nuanțat conștiința unității și a diferențierilor de grai.

În ansamblu, aceste comentarii provocate constituie aprecieri generale și exemple concrete referitoare la: a) gradul de asemănare dintre graiul localității anchetate și graiul altor localități învecinate (de exemplu, ,"tot așa (se vorbește)" - 357, 3832); b) diferențe, în grade diferite, între graiul localității anchetate și cel al localităților învecinate (de exemplu, se vorbește „,altfel” în satele vecine: ${ }^{3} 282$, 380, 387, 391, 418, 419, 437, 440 - „nici într-un sat nu se vorbește ca aici”, 446).

1 Comentariile au fost publicate în broșura anexă la vol. I al ALRR - Transilvania: ALRR - Transilvania. Date (1992).

2 Cifrele indică punctele cartografice din ALRR - Transilvania.

3 Având în vedere unitatea graiurilor dacoromâne (deși graiurile din Transilvania sunt neomogene și nu alcătuiesc un subdialect propriu-zis), considerăm că aceste aprecieri subiective nu se referă la deosebiri majore, care ar afecta înțelegerea între comunităţile învecinate. Vezi și Faiciuc 1985: 45. 
Majoritatea comentariilor se referă la diferențe între graiuri care vizează fapte de natură: a) fonetică: de exemplu, diftongul ịe provenit din vocala e precedată de consoana sonantă $r$ : vréme $>$ vriéme (392 1. v.), diftong considerat drept marcă a unui stadiu incipient de palatalizare a sonantei $r$ (cf. Tratat... 1984: 360), în sudul Transilvaniei (Țara Oltului); alternanța africatei $\hat{g}(<g+e, i)$ cu fricativa $j: f u \hat{g} /$ fuj, ĝińĕre / jijńere, júńĕre $(352,356)$, în aria sud-vestică; b) lexicală: de exemplu, termeni pentru noțiunea 'cartofi': piciócit (250 l.v., 294, 366), napi de oámeni (250), coroábe (291), hiríbe (291 1.v., 294 l.v), grúmpene (366 l.v.), crumpi (372), barabúle (372 1. v.); termeni referitori la forme pronominale: alternanța formelor scurte cu cele lungi ale demonstrativelor de depărtare: acéla, acéea (371) cu ála, áia (371 1. v.), ắla, áia (372) cu ceála, céea (372 l.v.).

2.2. Comentariile spontane sunt accidentale și generate de dorința de exprimare proprie a informatorului. Deși sunt mai numeroase în textele dialectale, unde subiectul se desfășoară mai liber, și în cursul anchetei dialectale bazate pe întrebări și răspunsuri s-a remarcat tendința informatorului de a observa și de a compara faptele de limbă. De altfel, ancheta dialectală nu este altceva decât un șir de fapte metalingvistice orientate, înainte de toate, asupra codului utilizat. Spre deosebire de comentariile provocate, comentariile spontane sunt pentru subiect o ocazie de a compara graiul său cu celelalte graiuri mai apropiate. Ele reprezintă în primul rând indicații cu rol de "glosare", de explicare suplimentară a termenului solicitat prin întrebarea din chestionar, provenind din dorința subiectului de a fi cât mai bine înțeles de către interlocutor (cf. Teaha 1970: 43). Este vorba despre aprecieri referitoare în special la fapte de natură lexicală, cuprinse în legendele hărților sau, în cadrul planșelor cu material necartografiat, imediat după punctul de anchetă. De exemplu:

[228] Gălăgie, I, h. 83, leg./299:" „lármă se spune la gălăžîize”;

[1396] Potârniche, IV, MN, pș. 115-116/296:6 „FUGLELE sunt mai mici”.

Precizările din legendele hărților exprimă uneori o întreagă paradigmă a termenilor dialectali din sfera unei noțiuni solicitate prin cuvântul-titlu, precum legenda hărții 66, I, [151] Pistrui, cuprinzând termeni adjectivali (cu variantele lor) din sfera noțiunii 'om pistruiat', complementari celor din hartă referitori la noțiunea 'pistrui', vizată de cuvântul-titlu:

4 Am prezentat termenii în ordinea crescătoare a punctelor de anchetă, nu în ordine alfabetică.

5 După numărul chestiunii (aflat între paranteze drepte), urmează numărul volumului, cu cifre romane, sigla și numărul hărții, sigla legendei (unde este cazul) și numărul cartografic al localității anchetate.

6 După numărul chestiunii, urmează numărul volumului, cu cifre romane, sigla pentru material necartografiat, numărul (numerele) planșei (planșelor) și numărul localității anchetate. 
[om] albinéț (246), alunós (454), burețát (252), burețós (259, 261, 265, 270, 277, 287), pắstrăv pe fáță (375), pătát pe obráz $(300,311,411)$, petát (pe fáță) $(364,441)$, péstriț (la piéle, la obráz) (299, 311, 312), pestriț (pă fáță) (301, 452), pistriț(ă) (281283, 302, 447), préstiț (i) (358), prestiț (363, 388), pristiț (340), pristít (382, 391, 438).

Legenda hărții 48, I, [121] Sașiu cuprinde sintagme verbale complementare răspunsurilor din hartă (termeni adjectivali din sfera noțiunii 'sașiu'):

se úită: boldiș (380), cruceát (372), cruciș (273, 281, 290, 349, 380, 407), în cruciș (254, 263, 282, 283), în cruci (460), crucișát (438), încrucișát (271, 446), ponciș (253);

véde: cruciș (262), curmeziș (420).

Precizările subiectului, ca observator al graiului, stabilesc diferențieri semantice între formele complementare după criterii precum:

a) forma sau dimensiunea obiectului:

[776] Ladă, III, MN, pș. 35/ 283: „cóstăn se numește cel cu tri fiìóŝ̌ĕ 'sertare’”;

[1233] Ragilă, IV, h. 487, leg./271: „La hęcelă dinții sunt mai mari ca la périiěn”;

b) materialul din care e confecționat obiectul:

[676] Portiță, III, h. 307, leg./374: „vrăńicúță se numește cea făcută din nuiele împletite, port'iță, cea din scânduri”;

[1514] Catrințăa, IV, h. 549, leg./ 441: „PĂSTURA e din postav și se îmbracă la sărbători”.

c) funcționalitatea/destinația obiectului:

[975] Coteț, III, h. 413, leg./422: „CĂTUȘA este pentru găini, COTONEAȚA, pentru rațe, gâște";

[1022] Răzor, IV, h. 429, leg./372: „Piatra sau stâlpul care se pune între locurile a doi proprietari se numește corhán; -hánée”.

Uneori, indicațiile subiectului se referă la frecvența termenilor din grai:

[576] Nuntă, I, h. 266, leg./250. 295: „uspắț se spune rar”;

[323] Mână, II, h. 152, leg./267. 289. 299. 326: „mîni, dar mai obișnuită este forma de plural mînurì".

Alteori, ele se referă la repartizarea teritorială a unui fapt lingvistic:

[311] Stomac, I, h. 145, leg./283: „aiíî să spúńĕ rî́ză”;

[1322] Făget, IV, MN, pș. 99-100/277: 'În localitatea vecină, Domnești, o pădure e numită făzết"'. 
Există și răspunsuri în care subiectul face distincția între formele mai vechi și cele mai recent intrate în grai, ${ }^{7}$ diferențele dintre forme fiind:

- de natură fonetică: [429] Medic, II, h. 190/421: dóctor, [V] dóftor; [614] Mireasă, II, h. 275/329: [V] mńiréáză, [R] mńirénásă;

- de natură lexicală: [125] Albeață, I, h. 52/309: [V] sáță pă uăâc, [R] alôáță; [770] Dop, III, h. 350/326: dop, [V] astupúș.

În anumite situații, precizările vizează:

- particularități de limbaj ale unor persoane de vârste diferite (tineri sau bătrâni):

[288] Gât, I, h. 110, leg./302: ,grumáz, mai bătrîneęștě”;

[641] Viu, II, h. 284/265: viun, [B] ziiu, iar în leg.: „,noi [cei mai tineri] nu mai zî́sěm żiù";

- diferențe de natură diastratică și diafazică:

[271] Amigdale, I, h. 112, leg./325: „mindál'e [e] mai pe domńęșt'ē”;

[399] Gleznă, II, h. 186, leg./292: „gl'éznă îi mai dúpă cárt'e";

- particularități individuale:

[469] Tată vitreg, II, h. 218, leg./456: „Ironic se spune tátă d'ě sálcă”;

[526] (Femeia) Naște, II, h. 255/456: náșt'ě, [V] fáce, în leg.: „Ironic se zice puiáză”.

3. Deși sunt influențate de factori subiectivi, extralingvistici, comentariile metalingvistice referitoare la variația dialectală ilustrează o realitate lingvistică concretă: existența obiectivă a diferențelor de grai, care permit delimitarea unor fenomene lingvistice și a unor arii dialectale.

Chiar dacă activitatea metalingvistică a nonlingvistului este, în cadrul anchetei dialectale, mai degrabă un fenomen de „inducție” (Vulpe 2004: 423), manifestat în cadrul relației dintre un „outsider" (anchetatorul) și un „insider” (subiectul anchetat), totuși, se poate afirma că ea oglindește o atitudine activă și conștientă față de limbaj.

Reacțiile subiectului sunt fenomene care reflectă subiectivitatea limbajului și tendința spre intensificare afectivă, proprie comunicării orale.

De asemenea, comentariile metalingvistice exprimă, pe lângă capacitatea de reflectare de către subiectul vorbitor a faptelor lingvistice aparținând

Utilizarea uneia sau a celeilalte forme se realizează după criterii de natură stilistică (Pușcariu 1936-1938: 430). Termenul recent este considerat de subiect mai frumos, de unde preferința pentru acesta. 
idiolectului propriu, și capacitatea de descriere și explicitare a acestora, ca formă de manifestare a conștiinței lingvistice, respectiv a unor abilități de dialectologie perceptivă, care vizează planul identitar. Abordarea fenomenului dialectal trebuie deci să se realizeze și prin prisma dimensiunii lui interacționale și sociale.

\section{Surse}

ALRR - Transilvania. Date = Atlasul lingvistic român pe regiuni - Transilvania . Date despre localități și informatori, București, Editura Academiei Române, 1992.

ALRR - Transilvania = Grigore Rusu, Viorel Bidian, Dumitru Loșonți, Atlasul lingvistic român pe regiuni - Transilvania, vol. I - IV, București, Editura Academiei Române, 1992-2006.

\section{Bibliografie}

Cazacu, Boris (1957). Sur la réaction du sujet parlant par rapport au fait linguistique, in: Mélanges linguistiques, publiés à l'occasion du VIIIe Congrès international des linguistes à Oslo, du 5 au 9 août 1957, București, pp. 189-199.

Colciar, Rozalia (2019). Comentarii metalingvistice în textul dialectal, in: Din dragoste de dascăl și de voroavă. Omagiu Doamnei Profesor Elena Dragoș - La aniversare [ed. Adrian Chircu, Maria Aldea] Cluj-Napoca: Casa Cărții de Știință, pp. 119-126.

Coșeriu, Eugen (1994). Lingvistica din perspectivă spațială și antropologică. Trei studii [cu o prefață de Silviu Berejan și un punct de vedere editorial de Stelian Dumistrăcel], Chișinău: „Știința”.

Dumistrăcel, Stelian, Hreapcă, Doina, Bîrleanu, Ion-Horia (1997). Ancheta dialectală ca formă de comunicare, Iași: Editura Academiei Române.

Faiciuc, Ioan (1985). Comentarii ale informatorilor privind variația dialectală. Note pe baza NALR-Banat, in: Anuar de lingvistică și istorie literară. A. Lingvistică, XXX, pp. 43-51.

Hoenigswald, Henry M. (1966). A proposal for the Study of Folk-Linguistics, in: Sociolinguistics. Proceedings of the UCLA Sociolinguistics Conference, The Hague-Paris, pp. 16-26.

Manu Magda, Margareta (2003). Elemente de pragmalingvistică a românei vorbite regional, București: Dual Tech.

Marin M., Marinescu, B. (1984). Graiurile din Transilvania, in: Tratat de dialectologie românească (Tratat...) [coord.: dr. Valeriu Rusu], Craiova: Scrisul Românesc, pp. 354-390.

Pușcariu, Sextil (1936-1938). Pe marginea cărților, in: Dacoromania, IX, pp. 403-446. Sala, Marius (1957). Remarques sur la réaction des sujets enquêtés pour l'«Atlas Linguistique Roumain», in: Mélanges linguistiques, publiés à l'occasion du VIIIe Congrès international des linguistes à Oslo, du 5 au 9 août 1957 (Mélanges Oslo...), București, pp. 189-199. 
Teaha, Teofil (1970). Un problème de métalinguistique: la réaction du sujet parlant dans le processus de la communication, in: Actes du Xe Congrès international des linguistes. Bucarest, 28 août-2 septembre 1967, II, București: Editura Academiei RSR, pp. 41-48.

Tratat... (1984) = Tratat de dialectologie românească [coord.: dr. Valeriu Rusu], Craiova: Scrisul Românesc.

Vulpe, Magdalena (2004). Comentarii metalingvistice în textele dialectale, in: Opera lingvistică I. Dialectal. Popular. Vorbit, Cluj-Napoca: Clusium, pp. 419423 [prima publicare: 1970].
Abrevieri
h. = hartă
1. v. = localitate (localități) vecină (vecine)
pș. = planșă
$\mathrm{MN}=$ material necartografiat
$\mathrm{R}=$ recent
$\mathrm{V}=$ vechi
$\mathrm{B}=$ bătrânii

\section{Descriptive attitude and meta-linguistic comment in ALRR - Transilvania}

The work approaches, based on material excerpted from ALRR - Transilvania, the way the speaker expresses his/her attitude/reaction towards the linguistic phenomena, from the simple perception of one's own idiom to the linguistic differences between two neighbouring idioms.

This attitude is expressed through meta-linguistic comments which differentiate the linguistic elements in the communication context and analyse them in an adequate metalanguage. ALRR - Transilvania registers: 1 . induced comments, asked and directed by the inquirer (general appreciations and concrete examples regarding the differences between the local speech and the speeches in the neighbouring localities); 2. spontaneous comments, accidental and generated by the speaker's desire (,indexing” indications for the term). The appreciations refer especially to phonetic and lexical aspects.

The meta-linguistic comments express, besides the speaker's ability to reflect the linguistic facts belonging to his/her own idiolect, the capacity to describe and explain them, as a form of linguistic consciousness. The approach of the dialectal phenomenon must, thus, be related to its interactional and social dimensions.

Key words: ALRR-Transilvania, descriptive attitude, meta-linguistic comment, induced comments, spontaneous comments 
